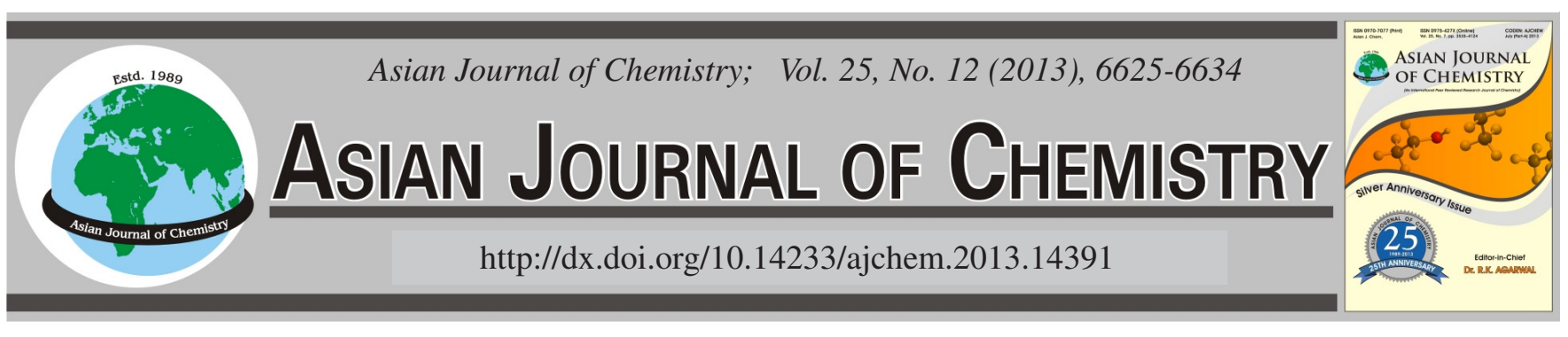

\title{
Simultaneous Electrochemical Determination of Dopamine, Epinephrine and Uric Acid at Silver Doped Poly-L-Cysteine Film Electrode
}

\author{
Wei Ma, Xue Yao and Dengming Sun ${ }^{*}$
}

School of Chemistry and Materials Science, Huaibei Normal University, 100 Dongshan Road, Huaibei 235000, Anhui Province, P.R. China *Corresponding author: E-mail: sundengming@126.com

\begin{abstract}
An electrochemical sensor based on silver doped poly-L-cysteine film (Ag-PLC) has been fabricated for simultaneous determination of dopamine, epinephrine and uric acid in the presence of ascorbic acid. Although bare GC electrode resolves the voltammetric signals of dopamine and epinephrine, it fails to resolve the signals of dopamine and uric acid in a mixture. However, the silver doped poly-L-cysteine film modified electrode not only separates the voltammetric signals of dopamine, epinephrine and uric acid with potential difference of 390 and $135 \mathrm{mV}$ vs. $\mathrm{Ag} / \mathrm{AgCl}$ between dopamine-epinephrine in cathodic peak potential and uric acid-(dopamine + epinephrine) in anodic peak potential, respectively, but also shows higher electrocatalytic activity towards dopamine, uric acid and epinephrine in the presence of high concentration of ascorbic acid. Under the optimized conditions, the electrochemical sensor exhibited linear responses for uric acid concentration over the range $5.00 \times 10^{-6}$ to $5.00 \times 10^{-5} \mathrm{~mol} \mathrm{~L}^{-1}$ and $5.00 \times 10^{-5}$ to $2.50 \times 10^{-4} \mathrm{~mol} \mathrm{~L}^{-1}$. The amperometric current response was also increased linearly with the increase of dopamine concentration in the range of $5.00 \times 10^{-6}$ to $1.10 \times 10^{-4} \mathrm{~mol} \mathrm{~L}^{-1}$. For epinephrine, the linear ranges were $5.00 \times 10^{-6}$ to $3.00 \times 10^{-5} \mathrm{~mol} \mathrm{~L}^{-1}$ and $3.00 \times 10^{-5}$ to $1.10 \times 10^{-4} \mathrm{~mol} \mathrm{~L}^{-1}$, respectively. The practical application for the present modified electrode was demonstrated by determining the concentration of dopamine, uric acid and epinephrine in human urine samples.
\end{abstract}

Key Words: L-Cysteine acid, Silver doped, Modified electrode.

\section{INTRODUCTION}

Dopamine (DA) and epinephrine (EP) were discovered to be two important catecholamine neurotransmitters in mammalian central nervous system in the late 1950s, which coexisted in the body fluid for controlling the nervous system in presence of other substances including uric acid, ascorbic acid, which always exist together in biological environment ${ }^{1}$.

As an important neuron-transmitter compound, dopamine plays a crucial physiological role and it is found in high concentration about $50 \mathrm{mmol} \mathrm{g}^{-1}$ in a region of the brain which affects brain processes such as movement controlling, emotional response, experiencing pleasure and pain, etc. ${ }^{2}$. The change of dopamine concentration is a symptom of some diseases such as parkinsonism and schizophrenia ${ }^{3}$.

Homoplastically, epinephrine is a catecholamine neurotransmitter hormone released from the adrenal gland and plays an important role as an extracellular chemical messenger which belongs to the family of excitatory chemical neurotransmitters in the mammalian central nervous system ${ }^{4,5}$. Many physiological phenomena are related to the variational concentration of epinephrine in blood. Moreover, epinephrine has been used as a common emergency healthcare drug $^{6}$, which exhibits a suppressive impact on the immune system and has been used to treat such diseases as cardiac arrest, asthma and sepsis ${ }^{7}$. Therefore, determination of epinephrine has attracted much attention of investigators for the study of the physiological functions.

Uric acid (UA) is a major primary end product from purine metabolism and its content diversification in human body can directly resulted in some diseases. The well-balanced uric acid level ranges from 240 to $520 \mu \mathrm{M}$ in serum and 1.4 to $4.4 \mathrm{mmol}$ $\mathrm{L}^{-1}$ commonly in urinary egesta for a healthy person ${ }^{8}$. It is known that hyper uric acid is a dangerous factor for fatal or nonfatal cerebrovascular accident to the patients who suffer from diseases of coronary heart and diabetes mellitus ${ }^{9}$. The abnormal concentration levels of uric acid in serum is often connected with gout, hypertension, cardiovascular, high blood pressure and cardiovascular disease, etc. ${ }^{10,11}$. So, the determination of uric acid in the human body fluid is significant for the clinical research.

Ascorbic acid (AA) is known as a vital vitamin in the human diet and it is commonly used to supplement inadequate dietary intake. It is found that ascorbic acid can be used to 
prevent or treat common cold, mental illness, infertility, cancer and $\operatorname{AIDS}^{12}$.

Due to their important roles in neurochemistry and industrial applications, some traditional measures have been taken for the determination of dopamine, epinephrine, uric acid and ascorbic acid ${ }^{13,14}$.

Chemical modified electrode is one of the exciting developments which have been widely used in the electroanalytical chemistry and biological fields ${ }^{15,16}$. Many different researches have been applied for the modification of the electrode surface. Amounts of different chemical modified electrode have been used for improving the sensitivity and selectivity of the sensor, such as electron-hole recombination ${ }^{17}$, electrochemical polymerization $^{18}$, sol-gel method ${ }^{19}$ and electrochemical pretreatment ${ }^{20}$, etc. The electrochemistry determination for biomaterial such as protein, enzyme ${ }^{21}$ has been greatly impelled with the development of polymer modified electrodes. The polymer film modified electrode is largely used because it has important functional groups with high density on the electrode surface and then it can improve the electrochemical activities and stability of the fixed functional groups ${ }^{22}$.

Amino acids are essential for lives and have been of greatly interest for both chemists and biologists. Great efforts have been made on its synthesis and determination ${ }^{23}$. It has been reported that amino acid molecules was used as modifier to decorate the electrode for the determination of the metal ions, biological substances and organic pollutants ${ }^{24}$. However, using amino acid solely as modifier to decorate the electrode have not been satisfied people's demand for the convenient and accurate determination.

Doping some substances on the surface of the electrode is an essential path for improving the efficiency of the modified electrode's electrochemical characters. The modified film exhibits a well-proportioned, steady-going and a good reduplicated character. Different structure and property of modified electrode films can be obtained by changing polymeric conditions. Lots of substances can be used to dope, such as metal ion, metal oxide, etc. There are also too many methods for doping i.e., microwave assisted chemical vaporization ${ }^{25}$, arc welding discharging ${ }^{26}$ and voice chemical techniques ${ }^{27}$, etc. A lot of metal-doped modified electrodes have been investigated, such as, $\mathrm{Fe}^{3+28,29}, \mathrm{Ru}$ and $\mathrm{Pt}^{30}$, lanthanide ${ }^{31}, \mathrm{Bi}^{32}$, etc. However, few research using amino acid as modifier and metal ion as doping substances to decorate the electrode has been reported in determining the compounds ${ }^{33}$.

It is known that dopamine, epinephrine, uric acid and ascorbic acid are frequently coexisted in biological fluids such as blood and urine. However, they are often oxidized at a contiguous potential which results in an overlapping voltammetric response at most traditional solid electrodes ${ }^{34}$. In addition, owing to the accumulation of oxidized products on the electrode surface, the solid electrodes, which exhibit rather poor selectivity and sensitivity, suffer from the fouling effect. An enormous amount of research has been devoted to the determination of dopamine, epinephrine and uric acid using chemical modified electrode. However, many of these studies have been limited to the determination of a single or two components ${ }^{35-38}$. Moreover, it is always too hard to selectively determine dopamine, epinephrine and uric acid simultaneously in the presence of high concentrations of ascorbic acid ${ }^{39,40}$. In order to resolve the problem mentioned above, a new modified electrode must be fabricated, which can achieve the simultaneous determination of dopamine, epinephrine and uric acid in the presence of ascorbic acid.

In this paper, the fabrication of silver doped poly-Lcysteine film electrode (Ag-PLC/GCE) was prepared by cyclic sweep and the electrochemical behaviours of dopamine, epinephrine and uric acid at the modified electrode were discussed. The simultaneous determination of dopamine, epinephrine and uric acid at Ag-PLC/GCE was studied. Due to the silver doped, the electrochemical response, such as the electron transfer, peak separations and sensitivity of the modified electrode, were enhanced obviously. The modified electrode can be constructed as a biosensor which demonstrated by detecting the concentration of dopamine, epinephrine and uric acid in injection solution and human urines.

\section{EXPERIMENTAL}

Dopamine, epinephrine, uric acid and ascorbic acid (Sigma) were freshly prepared before use. L-Cysteine, used in electro polymerization as a monomer, was acquired from Guoyao chemical reagent corporation (Shanghai, China). Phosphate buffer solutions were prepared by using $0.1 \mathrm{~mol} \mathrm{~L}^{-1}$ $\mathrm{Na}_{2} \mathrm{HPO}_{4}-\mathrm{NaH}_{2} \mathrm{PO}_{4}$ and the $\mathrm{pH}$ was adjusted with $0.1 \mathrm{~mol} \mathrm{~L}^{-1}$ $\mathrm{Na}_{3} \mathrm{PO}_{4}$ and $\mathrm{H}_{3} \mathrm{PO}_{4}$. All chemicals were of analytical-reagent grade. All the solutions were prepared with doubly distilled deionized water and all the experiments were carried out at room temperature. High purity nitrogen was applied for deaeration.

The electrochemical study was performed with BAS100/ W electrochemical workstation (BAS group, USA). The threeelectrode system consisted of a silver doped poly-L-cysteine film electrode (Ag-PLC/GCE) as a working electrode, a Pt wire as an auxiliary electrode and a saturated $\mathrm{Ag} / \mathrm{AgCl}$ as a reference electrode. A digital $\mathrm{pH} / \mathrm{mV}$ meter (PHS-3C, Shanghai, China) with a combined electrode was utilized in $\mathrm{pH}$ measurement.

The bare GCE was polished with $0.05 \mu \mathrm{m}$ alumina slurry and a polishing cloth to obtain a mirror surface. After each polishing, it was rinsed with $1: 1 \mathrm{HNO}_{3}$, ethanol and ultrasonicated in doubly distilled deionized water for $5 \mathrm{~min}$ to remove any adhesive substances on the electrode surface, respectively. After cleaning, electropolymerization of silver doped poly L-cysteine (Ag-PLC) on the GCE was modified with silver nitrate and L-Cysteine by 10 cycles from 2.4 to $-0.9 \mathrm{~V}$ at a scan rate of $100 \mathrm{mV} \mathrm{s}^{-1}$ in the solution containing $4.5 \mathrm{mmol} \mathrm{L}^{-1} \mathrm{~L}$-cysteine, $0.5 \mathrm{mmol} \mathrm{L}^{-1} \mathrm{AgNO}_{3}, 0.025 \mathrm{~mol} \mathrm{~L}^{-1}$ $\mathrm{KNO}_{3}$ and $0.064 \mathrm{~mol} \mathrm{~L}^{-1} \mathrm{HNO}_{3}$. Finally, the electrode's surface was rinsed by doubly distilled deionized water.

The experiments were performed by cyclic voltammograms from -0.50 to $0.60 \mathrm{~V}$ at $100 \mathrm{mV} \mathrm{s}^{-1}$ in $\mathrm{pH} 7.5$ phosphate buffer solutions with the quiet time of $8 \mathrm{~s}$. After each sweep, the electrode was put into the blank solution until the peak faded away.

\section{RESULTS AND DISCUSSION}

Electropolymerization of silver doped poly L-cysteine (Ag-PLC) film at the GCE surface: Fig. 1 shows the cyclic 
voltammograms of polymerization under the optimum conditions. As can be seen, in the first potential sweep, an obvious wide cathodic peak was appeared at the peak potential of $-0.5 \mathrm{~V}$ and the peak potential was almost unchanged with gradual decrease of the peak current in the following 9 cycles. When the polymerization was finished, a certain puce black substance was observed on the electrode surface.

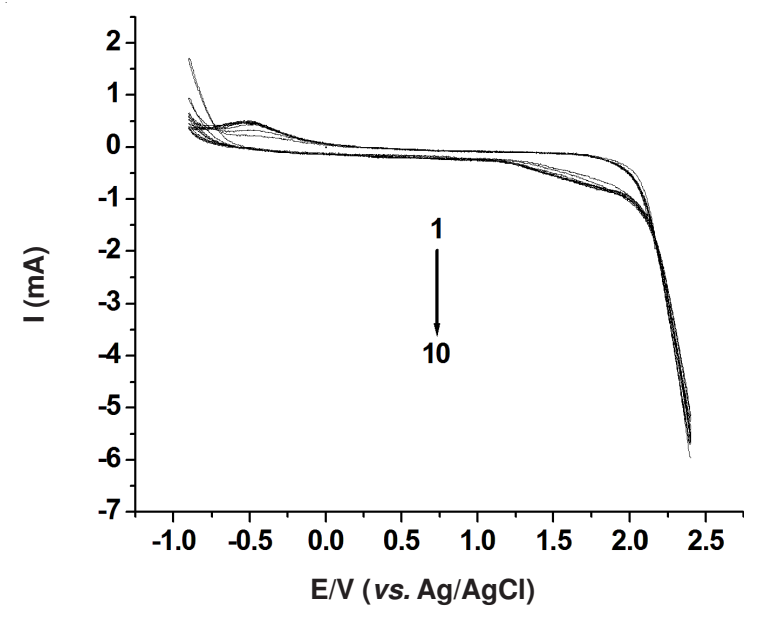

Fig. 1. Cyclic voltammetric curves of the polymerization process at scan rate of $100 \mathrm{mV} \mathrm{s}^{-1}$. From 1 to 10 indicate the total number of sweeps

Electrochemical behaviour of dopamine at the Ag-PLC/ GCE: In order to test the electrocatalytic activity of the electrode, the cyclic voltammograms at a bare GCE, Ag/GCE, PLC/GCE and Ag-PLC/GCE were obtained in $5.00 \times 10^{-5} \mathrm{~mol}$ $\mathrm{L}^{-1}$ dopamine. From Fig. 2, dopamine shows a pair of redox peaks with a peak potential separation $\left(\Delta \mathrm{E}_{\mathrm{p}}\right)$ of $50 \mathrm{mV}\left(\mathrm{E}_{\mathrm{pa}}=\right.$ $273 \mathrm{mV} v s . \mathrm{Ag} / \mathrm{AgCl}, \mathrm{E}_{\mathrm{pc}}=223 \mathrm{mV}$ vs. $\left.\mathrm{Ag} / \mathrm{AgCl}\right)$ at bare $\mathrm{GCE}$. But at Ag/GCE, PLC/GCE and Ag-PLC/GCE, the peak current increased obviously. The voltammograms presented a couple of reversible redox peaks with an $\Delta \mathrm{E}_{\mathrm{p}}$ of only $32 \mathrm{mV}\left(\mathrm{E}_{\mathrm{pa}}=\right.$ $259 \mathrm{mV} v s . \mathrm{Ag} / \mathrm{AgCl}$ and $\mathrm{E}_{\mathrm{pc}}=227 \mathrm{mV} v$ s. $\mathrm{Ag} / \mathrm{AgCl}$ ) at Ag-PLC/GCE, while the oxidation and the reduction peak potential were $253 \mathrm{mV}, 254 \mathrm{mV}, 227 \mathrm{mV}$ and $218 \mathrm{mV} v$ s. Ag/ $\mathrm{AgCl}$ at the $\mathrm{Ag} / \mathrm{GCE}$ and $\mathrm{PLC} / \mathrm{GCE}$, respectively. Compared with other modified electrodes, the highest peak current at the Ag-PLC/GCE shows an obvious catalytic effect of the modified Ag-PLC film. Based upon the equation, $\Delta \mathrm{E}_{\mathrm{p}}=0.059 / \mathrm{n}^{41}$, the number of electrons transferred was calculated to be 2 .

To study the effect of $\mathrm{pH}$ on the response of dopamine, cyclic voltammograms at the Ag-PLC/GCE were recorded for dopamine in a range of $\mathrm{pH}$ from 2.5 to 11.0, as shown in Fig. 3. All the peak potential for the dopamine shifted to negative potential with an increase of $\mathrm{pH}$, showing that protons have taken part in the electrode reaction processes. The $\mathrm{E}_{\mathrm{p}} \sim \mathrm{pH}$ relationship for dopamine could be expressed with equations: $\mathrm{E}_{\mathrm{pa}}=0.5977-0.05376 \mathrm{pH}, \mathrm{r}=0.9948 ; \mathrm{E}_{\mathrm{pc}}=0.5591-0.05615$ pH, $\mathrm{r}=0.9984$, (Fig. 3B)

The slopes of $53.8 \mathrm{mV} \mathrm{pH}^{-1}$ and $56.2 \mathrm{mV} \mathrm{pH}^{-1}$ (close to the theoretical value of $59 \mathrm{mV} \mathrm{pH}^{-1}$ ) reveal that the number of the protons in the process of the redox reaction of dopamine are equal to the number of the transferred electrons. Fig. 3A shows that the peak current of dopamine increases slightly with an increase in the solution $\mathrm{pH}$ until it reaches 6.

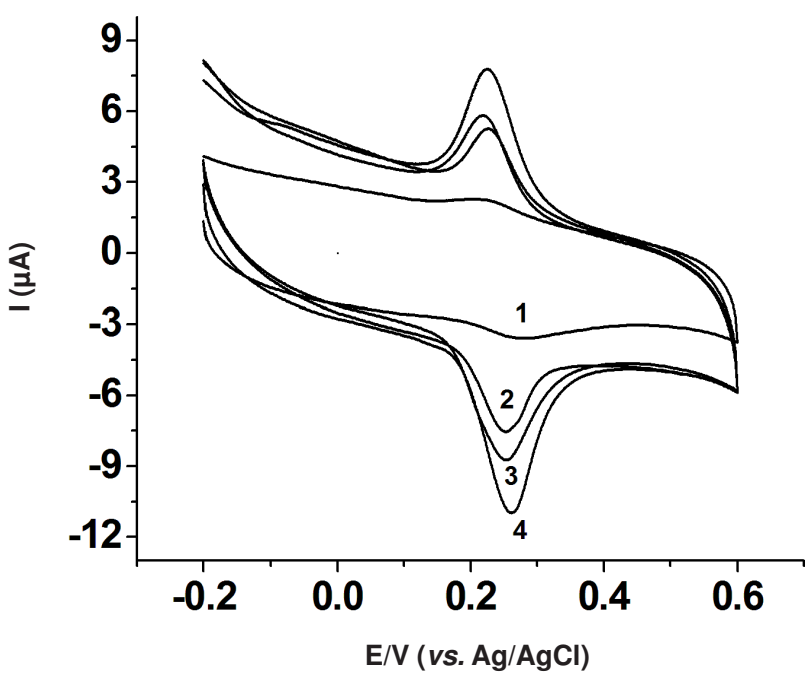

Fig. 2. Cyclic voltammograms of dopamine at GCE (1), Ag/GCE (2), PLC/ GCE (3) and Ag-PLC/GCE (4). $\mathrm{C}_{\mathrm{DA}}: 5.00 \times 10^{-5} \mathrm{~mol} \mathrm{~L}^{-1}$; scan rate: $100 \mathrm{mV} \mathrm{s}^{-1} ; \mathrm{pH} 6$ PBS
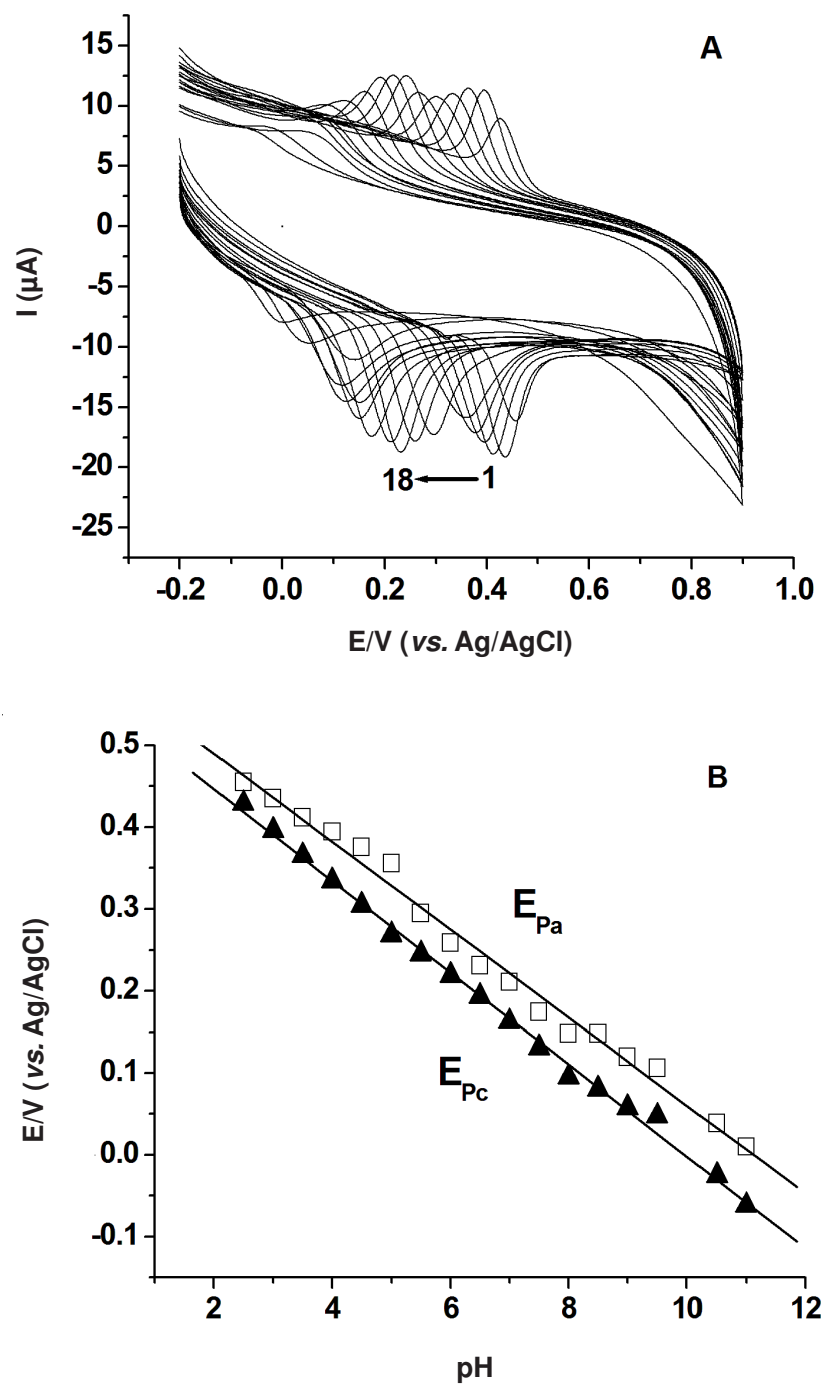

Fig. 3. Effects of $\mathrm{pH}$ at Ag-PLC/GCE on the cyclic voltammetric response of $5.00 \times 10^{-5} \mathrm{~mol} \mathrm{~L}^{-1}$ dopamine $(\mathrm{A})$ and the relationship curve between the peak potential and $\mathrm{pH}(\mathrm{B})$. Scan rate: $100 \mathrm{mV} \mathrm{s}^{-1} ; \mathrm{pH}$ from 1 to $18: 2.5,3.0,3.5,4.0,4.5,5.0,5.5,6.0,6.5,7.0,7.5,8.0$, $8.5,9.0,9.5,10.0,10.5,11.0$ 
In accordance with the electrochemical reaction of dopamine ${ }^{42}$, the electrode reaction mechanism could be described as:

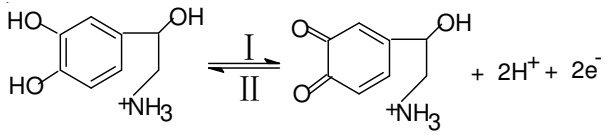

The oxidation and reduction peak current of the dopamine at the Ag-PLC/GCE were recorded at different scan rates (from 20 to $600 \mathrm{mV} \mathrm{s}^{-1}$ ) and the results are shown in Fig. 4. Fig. 4(B) illustrates that the peak currents $\left(\mathrm{I}_{\mathrm{p}}\right)$ versus the square root of scan rate were linearly from 20 to $520 \mathrm{mV} \mathrm{s}^{-1}$ with the regression equations of $\mathrm{I}_{\mathrm{pa}}=-7.826 \times 10^{-6}+2.398 \times 10^{-6} \mathrm{v}^{0.5}, \mathrm{r}=$ 0.9993 and $\mathrm{I}_{\mathrm{pc}}=-5.715 \times 10^{-6}+2.082 \times 10^{-6} \mathrm{v}^{0.5}, \mathrm{r}=0.9970$, respectively. The equations clearly indicate that a diffusion controlled process of dopamine at Ag-PLC/GCE. Fig. 4(C) shows the peak potentials $\mathrm{E}_{\mathrm{pa}}$ and $\mathrm{E}_{\mathrm{pc}}$ as a function of the potential sweep rate. The values of $E_{p}$ were proportional to the logarithm of the scan rate over the range of $100-600 \mathrm{mV} \mathrm{s}^{-1}$. The following regression equations were acquired: $\mathrm{E}_{\mathrm{pa}}=89.15$ $+90.64 \operatorname{lgv}, \mathrm{r}=0.9962 ; \mathrm{E}_{\mathrm{pc}}=329.9-59.061 \mathrm{gv}, \mathrm{r}=0.9959$.

Based on the following equations ${ }^{43}$ :

$$
\begin{aligned}
& \mathrm{E}_{\mathrm{pa}}=\mathrm{A}+\left(2.303 \mathrm{RT} /(1-\alpha) \mathrm{n}_{\alpha} \mathrm{F}\right) \lg \mathrm{v} \\
& \mathrm{E}_{\mathrm{pc}}=\mathrm{B}-\left(2.303 \mathrm{RT} / \alpha \mathrm{n}_{\alpha} \mathrm{F}\right) \lg \mathrm{v}
\end{aligned}
$$
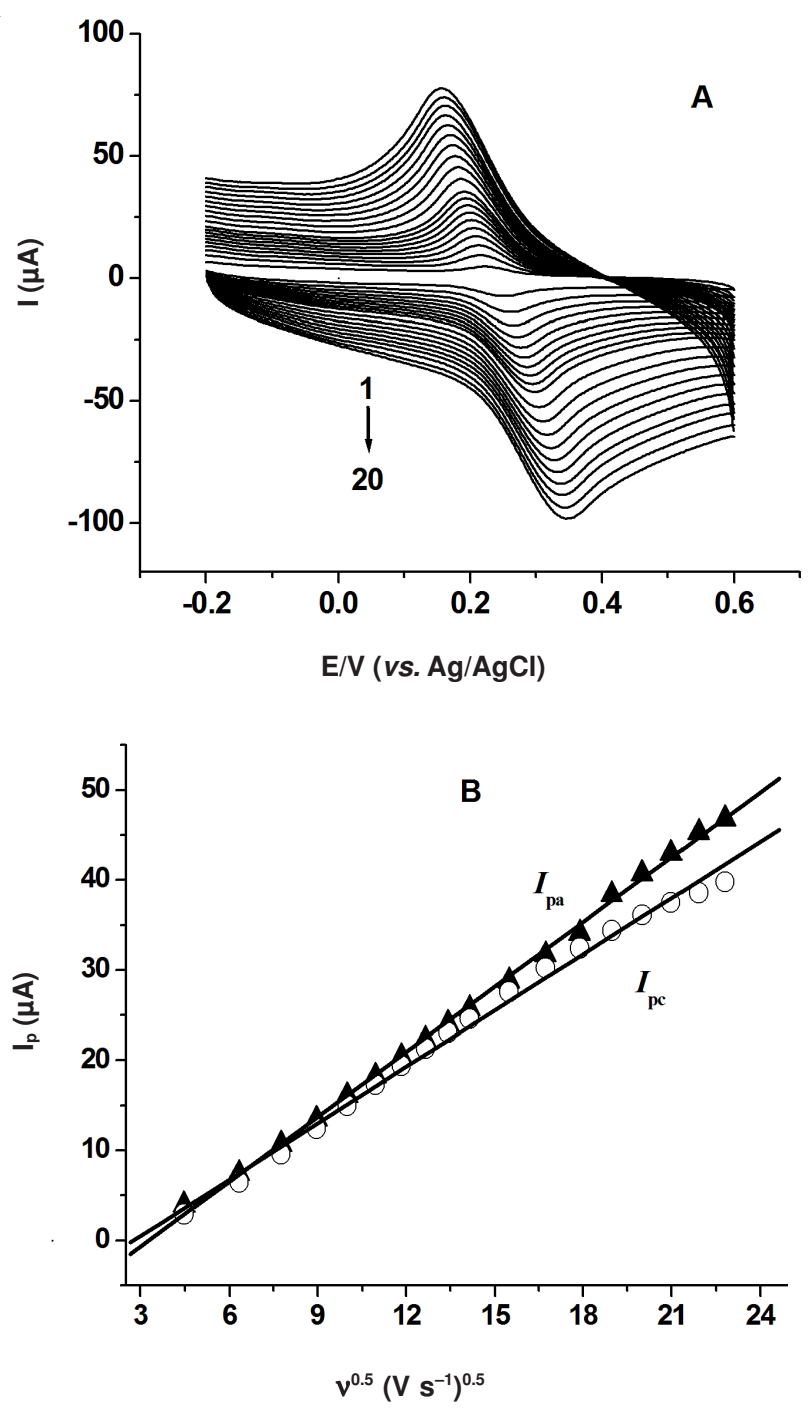

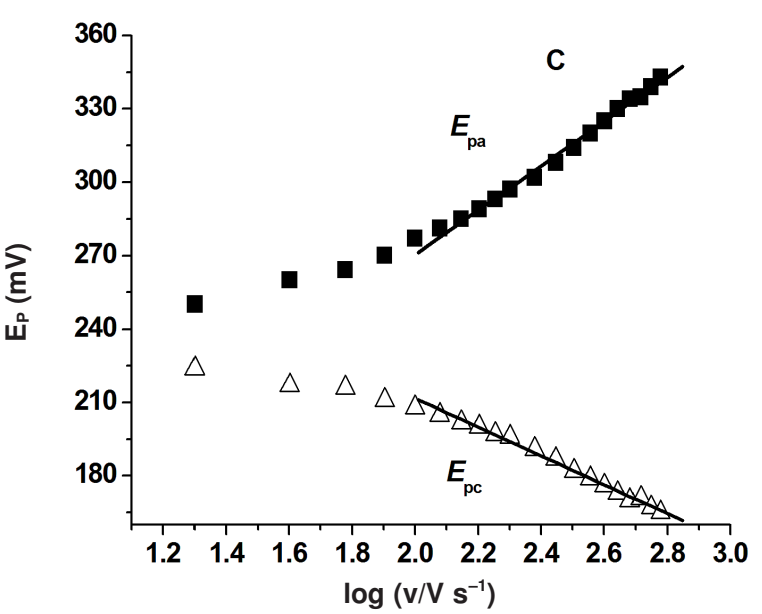

Fig. 4 (A) Cyclic voltammograms of $5.00 \times 10^{-5} \mathrm{~mol} \mathrm{~L}^{-1}$ dopamine at AgPLC/GCE in pH 6.0 PBS. scan rate from 1 to 20: 20, 40, 60, 80, $100,120,140,160,180,200,240,280,320,360,400,440,480$, 520,560 and $600 \mathrm{mV} \mathrm{s}^{-1}$. (B) The relationship curve between $\mathrm{I}_{\mathrm{p}}$ and $\mathrm{n}_{1} / 2$. (C) plot of $\mathrm{E}_{\mathrm{pa}}$ and $\mathrm{E}_{\mathrm{pc}}$ versus $\log \mathrm{v}$

The transfer coefficient a could be calculated from the slope of the equation and was found to be 0.606 . It indicates the electrode process is quasi-reversible in the range of $100-600 \mathrm{mV} \mathrm{s}^{-1}$.

While $=240 \mathrm{mV} \mathrm{s}^{-1}, \Delta \mathrm{E}_{\mathrm{p}}=111 \mathrm{mV}$ and then $\mathrm{n} \Delta \mathrm{E}_{\mathrm{p}}>200$ $\mathrm{mV}$, the standard rate constant $\mathrm{k}_{\mathrm{s}}$ could be calculated to be $1.11 \mathrm{~s}^{-1}$ using eqn. $3^{43}$.

$\lg \mathrm{k}_{\mathrm{s}}=\alpha \lg (1-\alpha)+(1-\alpha) \lg \alpha-\lg \frac{\mathrm{RT}}{\mathrm{n}_{\alpha} \mathrm{Fv}}-\frac{\alpha(1-\alpha) \mathrm{n}_{\alpha} \mathrm{F} \Delta \mathrm{E}}{2.3 \mathrm{RT}}$

Electrochemical behaviour of epinephrine at the AgPLC/GCE: Fig. 5 shows the cyclic voltammograms obtained from $5.00 \times 10^{-5} \mathrm{~mol} \mathrm{~L}^{-1}$ epinephrine at the bare $\mathrm{GCE}$, the $\mathrm{Ag}$ / GCE, the PLC/GCE and the Ag-PLC/GCE in $\mathrm{pH} 3.5$ phosphate buffer solutions, respectively. As can be seen, a small response of epinephrine was observed at the bare GCE. In contrast, at the Ag-PLC/GCE, the peak currents were enhanced with $\Delta \mathrm{E}_{\mathrm{p}}$ of 81 $\mathrm{mV}\left(\mathrm{E}_{\mathrm{pa}}=457 \mathrm{mV}\right.$ vs. $\mathrm{Ag} / \mathrm{AgCl}, \mathrm{E}_{\mathrm{pc}}=376 \mathrm{mV}$ vs. $\left.\mathrm{Ag} / \mathrm{AgCl}\right)$, while the $\mathrm{E}_{\mathrm{pa}}$ and the $\mathrm{E}_{\mathrm{pc}}$ were 438, 437, 389 and $375 \mathrm{mV} v \mathrm{~s} . \mathrm{Ag} /$ $\mathrm{AgCl}$ at the $\mathrm{Ag} / \mathrm{GCE}$ and PLC/GCE, respectively. The cyclic voltammograms shows that the Ag-PLC film has an obvious catalytic activity for the redox reaction of epinephrine.

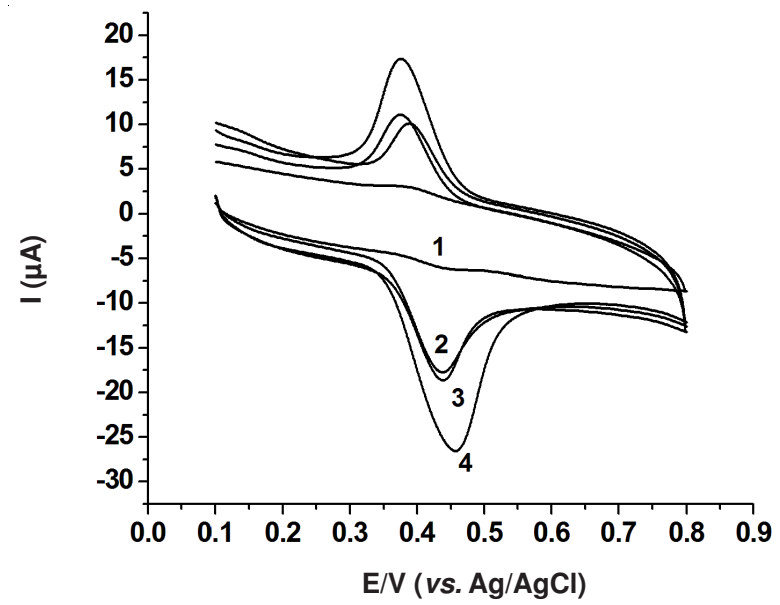

Fig. 5. Cyclic voltammograms of epinephrine at GCE (1), Ag/GCE (2), PLC/GCE (3) and Ag-PLC/GCE (4). C $\mathrm{EP}_{\mathrm{BP}}: 5.00 \times 10^{-5} \mathrm{~mol} \mathrm{~L}^{-1}$; scan rate: $100 \mathrm{mV} \mathrm{s}^{-1}$; $\mathrm{pH} 3.5 \mathrm{PBS}$ 
The effects of $\mathrm{pH}$ were studied by cyclic voltammetry from $\mathrm{pH} 2$ to 11 at a scan rate of $100 \mathrm{mV} \mathrm{s}^{-1}$. In Fig. 6A, the cyclic voltammograms shows that all the anodic and cathodic peaks for the epinephrine shifted to more negative potential with an increase in $\mathrm{pH}$, indicating that the proton has taken part in the electrode reaction processes. The increase of $\mathrm{pH}$ led to the anodic peak potential with a slope of $61.4 \mathrm{mV} \mathrm{pH}^{-1}$ as shown in Fig. 6(B) $\left(\mathrm{E}_{\mathrm{pa}}=0.6591-0.06135 \mathrm{pH}, \mathrm{r}=0.9937\right)$, which suggests that the same number of electrons and protons took part in the redox reaction of epinephrine. With the increase of $\mathrm{pH}$ value, the anodic peak current of epinephrine increased obviously from $\mathrm{pH} 2.5$ to 7.5 and the maximum value was observed at $\mathrm{pH}$ 7.5. The phenomenon of the electrochemical reaction for epinephrine in this experiment was in accordance with previous work $^{44}$.
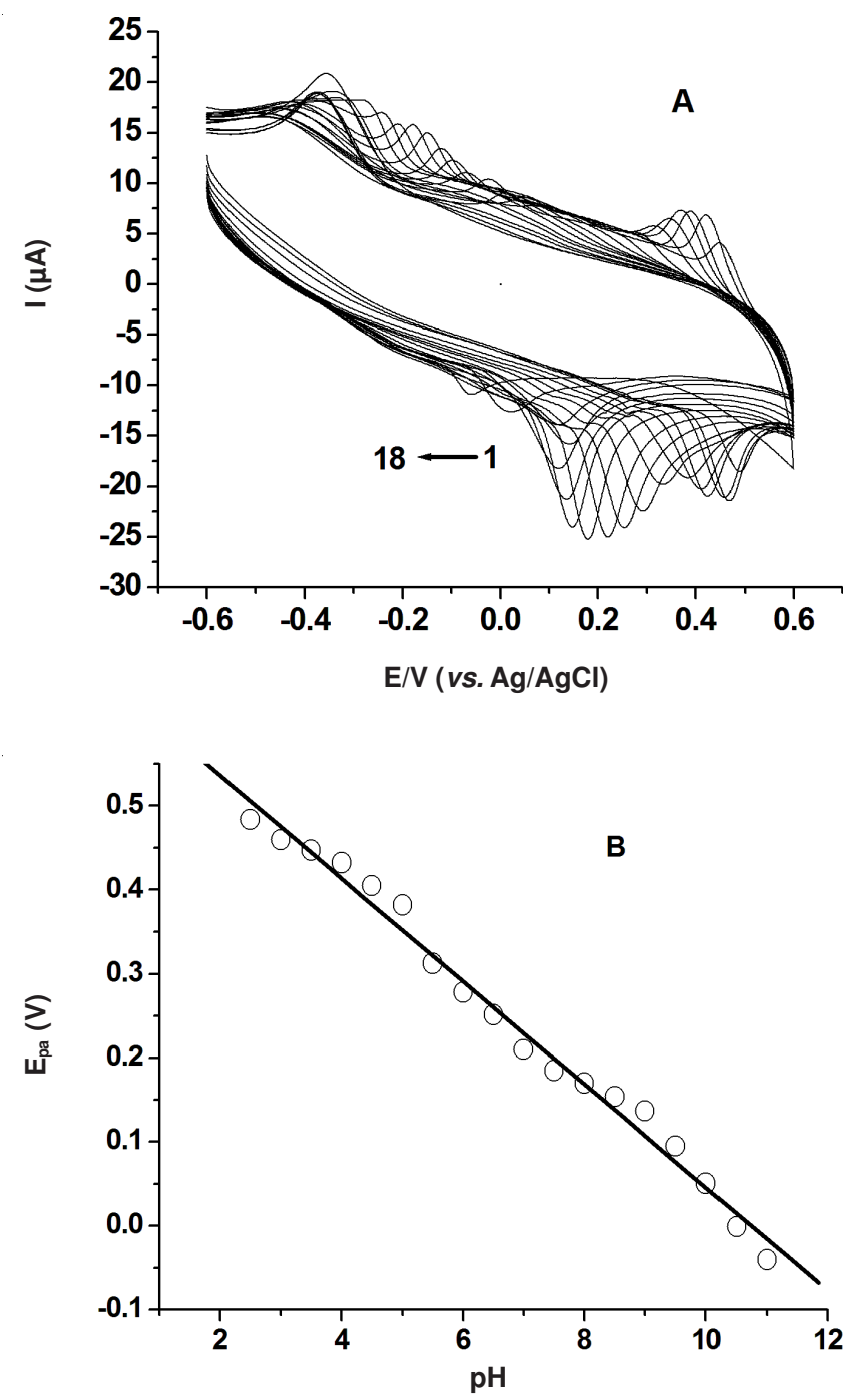

Fig. 6. Effects of $\mathrm{pH}$ at the Ag-PLC/GCE on the cyclic voltammetric response of $5.00 \times 10^{-5} \mathrm{~mol} \mathrm{~L}^{-1}$ epinephrine (A) and the relationship curve between the peak potential versus $\mathrm{pH}(\mathrm{B})$. Scan rate: $100 \mathrm{mV}$ $\mathrm{s}^{-1} ; \mathrm{pH}$ from 1 to $18: 2.5,3.0,3.5,4.0,4.5,5.0,5.5,6.0,6.5,7.0$, $7.5,8.0,8.5,9.0,9.5,10.0,10.5,11.0$

Fig. 7 shows the effect of scan rate on the response of epinephrine in the range from 20 to $800 \mathrm{mV} \mathrm{s}^{-1}$. Fig. 7(B) illustrates that the anodic and cathodic peak currents $\left(\mathrm{I}_{\mathrm{p}}\right)$ were proportional to the square root of scan rate from 20 to $800 \mathrm{mV}$ $\mathrm{s}^{-1}$ and the regression equations were: $\mathrm{I}_{\mathrm{pa}}=-5.405 \times 10^{-6}+1.576$ $\times 10^{-6} v 0.5$ and $\mathrm{I}_{\mathrm{pc}}=-5.427 \times 10^{-6}+1.320 \times 10^{-6} \mathrm{v}^{0.5}$, with the correlation coefficient of 0.9991 and 0.9989 , respectively. The linear correlation obviously shows that the redox currents of epinephrine were diffusion controlled at Ag-PLC/GCE. Furthermore, Fig. 7(C) shows that the peak potentials $\mathrm{E}_{\mathrm{pa}}$ and $\mathrm{E}_{\mathrm{pc}}$ exhibited a linear relation to the logarithm of the scan rate in the range from 100 to $800 \mathrm{mV} \mathrm{s}^{-1}$ with the regression equations of: $\mathrm{E}_{\mathrm{pa}}=268.6+81.28 \lg \mathrm{v}, \mathrm{r}=0.9906 ; \mathrm{E}_{\mathrm{pc}}=508.8-62.61 \lg \mathrm{v}$, $\mathrm{r}=0.9946$. Based on the reference ${ }^{45}$, the slope equals to 2.303 $\mathrm{RT} /(1-\alpha) \mathrm{n}_{\alpha} \mathrm{F}$ and $-2.303 \mathrm{RT} / \alpha \mathrm{n}_{\alpha} \mathrm{F}$. Therefore, The electron transfer coefficient $\alpha$ could be calculated to be 0.56 .

Electrochemical oxidation of uric acid at the Ag-PLC/ GCE: Fig. 8 shows the cyclic voltammograms of uric acid at bare GCE (1) Ag/GCE (2) PLC/GCE (3) and Ag-PLC/GCE (4) in pH 7.5 phosphate buffer solutions. A broad and much smaller peak response with the potential of $0.325 \mathrm{~V}$ at bare GCE was observed, indicating slow electron transfer kinetics, mainly due to the fouling of the electrode surface by oxidation product of uric acid. But at the other three modified electrodes, all voltammograms presented a pair of redox peaks with the anodic and the cathodic peak potential of 0.325 and $0.279 \mathrm{~V}$ at Ag/GCE, 0.324 and $0.286 \mathrm{~V}$ at PLC/GCE, 0.334 and $0.295 \mathrm{~V}$
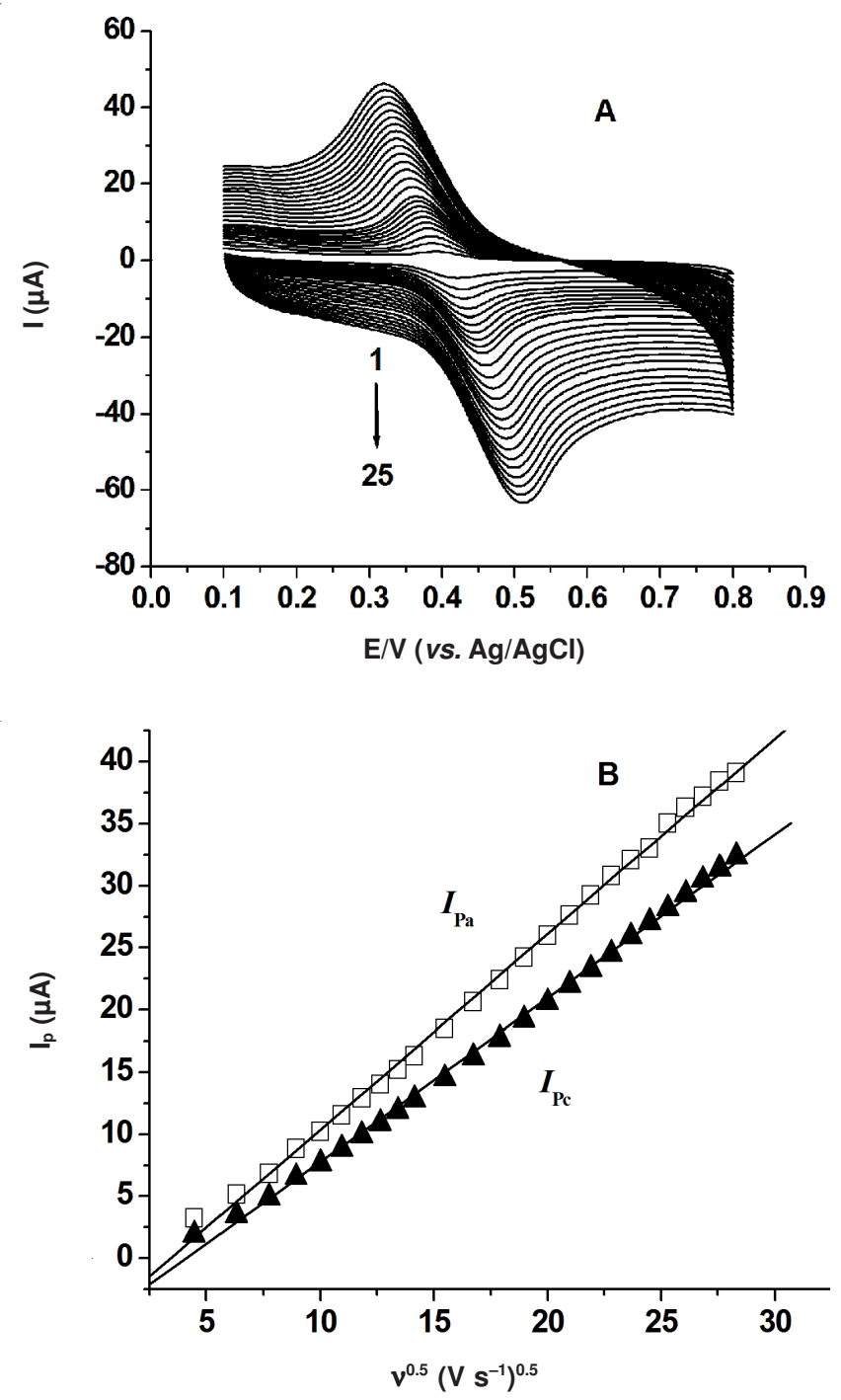


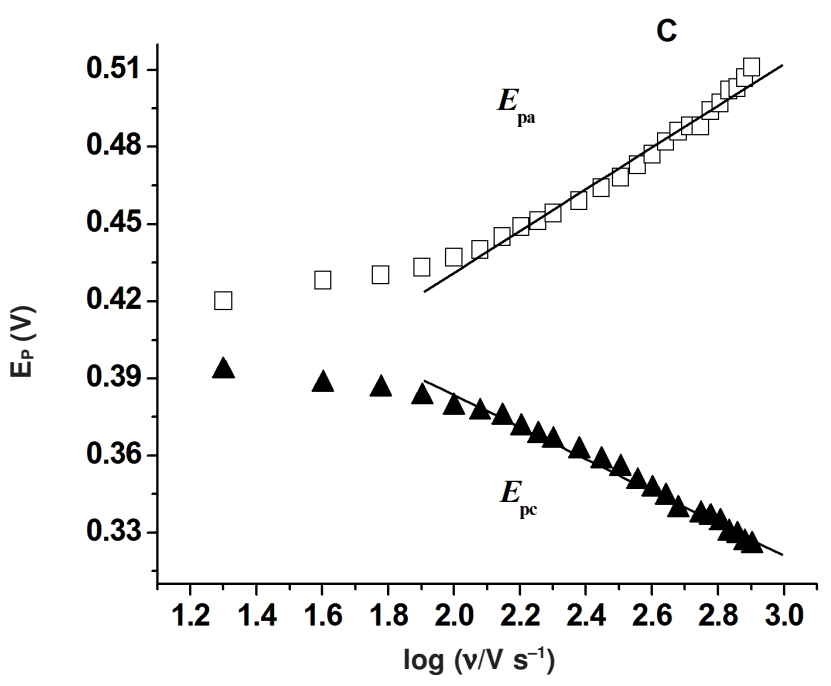

Fig. 7. (A) Cyclic voltammograms of $5.00 \times 10^{-5} \mathrm{~mol} \mathrm{~L}^{-1} \mathrm{EP}$ at Ag-PLC/ GCE in pH 3.5 PBS. Scan rate from 1 to $25: 20,40,60,80,100$, $120,140,160,180,200,240,280,320,360,400,440,480,520$, $560,600,640,680,720,760$ and $800 \mathrm{mV} \mathrm{s}^{-1}$. (B) The relationship curve between $\mathrm{I}_{\mathrm{p}}$ and $v^{1 / 2}$. (C) A plot of $\mathrm{E}_{\mathrm{pa}}$ and $\mathrm{E}_{\mathrm{pc}}$ versus $\log v$

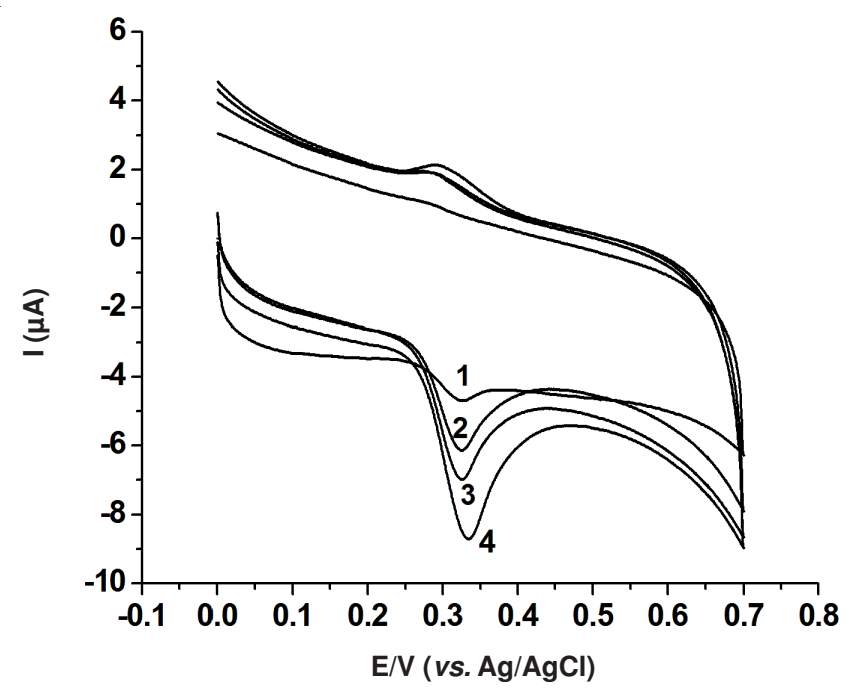

Fig. 8. Cyclic voltammograms of $6.00 \times 10^{-5} \mathrm{~mol} \mathrm{~L}^{-1} \mathrm{UA}$ at GCE (1), Ag/ GCE (2), PLC/GCE (3) and Ag-PLC/GCE (4). Scan rate: $50 \mathrm{mV} \mathrm{s}^{-1}$; $\mathrm{pH} 7.5$

at Ag-PLC/GCE, respectively. Although the peak potential for the oxidation of uric acid at Ag/GCE, PLC/GCE and Ag-PLC/ GCE were almost the same, an enhanced peak current was observed at Ag-PLC/GCE, indicating an enhanced catalytic effect on uric acid with the Ag-PLC film.

The effect of solution $\mathrm{pH}$ was investigated. From $\mathrm{pH} 2.5$ to 11 , the anodic peak potential $\left(\mathrm{E}_{\mathrm{pa}}\right)$ shifted negatively with the increase in $\mathrm{pH}$. The relationship of $\mathrm{E}_{\mathrm{pa}}$ versus $\mathrm{pH}$ could be expressed with the equations of $\mathrm{E}_{\mathrm{pa}}(\mathrm{V})=0.8120-0.06275$ $\mathrm{pH}, \mathrm{r}=0.9914$, the peak potential shows a slope of $-62.7 \mathrm{mV}$ $\mathrm{pH}^{-1}$ for uric acid oxidation, which suggests that the same number of electrons and protons took part in the electrode reaction processes. It has already been reported that the electrochemical oxidation of uric acid is oxidized by a two electron two proton process, followed by a hydrolytic reaction to produce a precarious diimine substances and then affected by water molecules in a stepwise ways to be diverted into an imine-alcohol and uric acid-4,5 diol. The uric acid -4,5 diol compound is so active $\mathrm{e}^{45}$ and a majority of it was decompounded to allantoin, as shown the following:

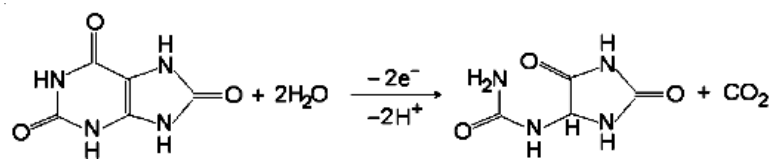

The scan rate dependence of the cyclic voltammogram response of uric acid at Ag-PLC/GCE is shown in Fig. 9. With the increase of scan rate, the oxidation peak potential was shifted positively and the peak current was increased too. A linear relationship between the logarithm of anodic peak current and the logarithm of scan rate in the range of 20 to $800 \mathrm{mV} \mathrm{s}^{-1}$ was proportional as $\lg \mathrm{I}_{\mathrm{pa}}=-6.613+0.6825 \mathrm{lg} \mathrm{v}, \mathrm{r}=0.9984$, suggesting that the catalytic oxidation processes of uric acid were mainly controlled by the diffusion.

Electrochemical behaviour of dopamine, epinephrine and uric acid at the Ag-PLC/GCE: The simultaneous determination of epinephrine, dopamine and uric acid are shown in
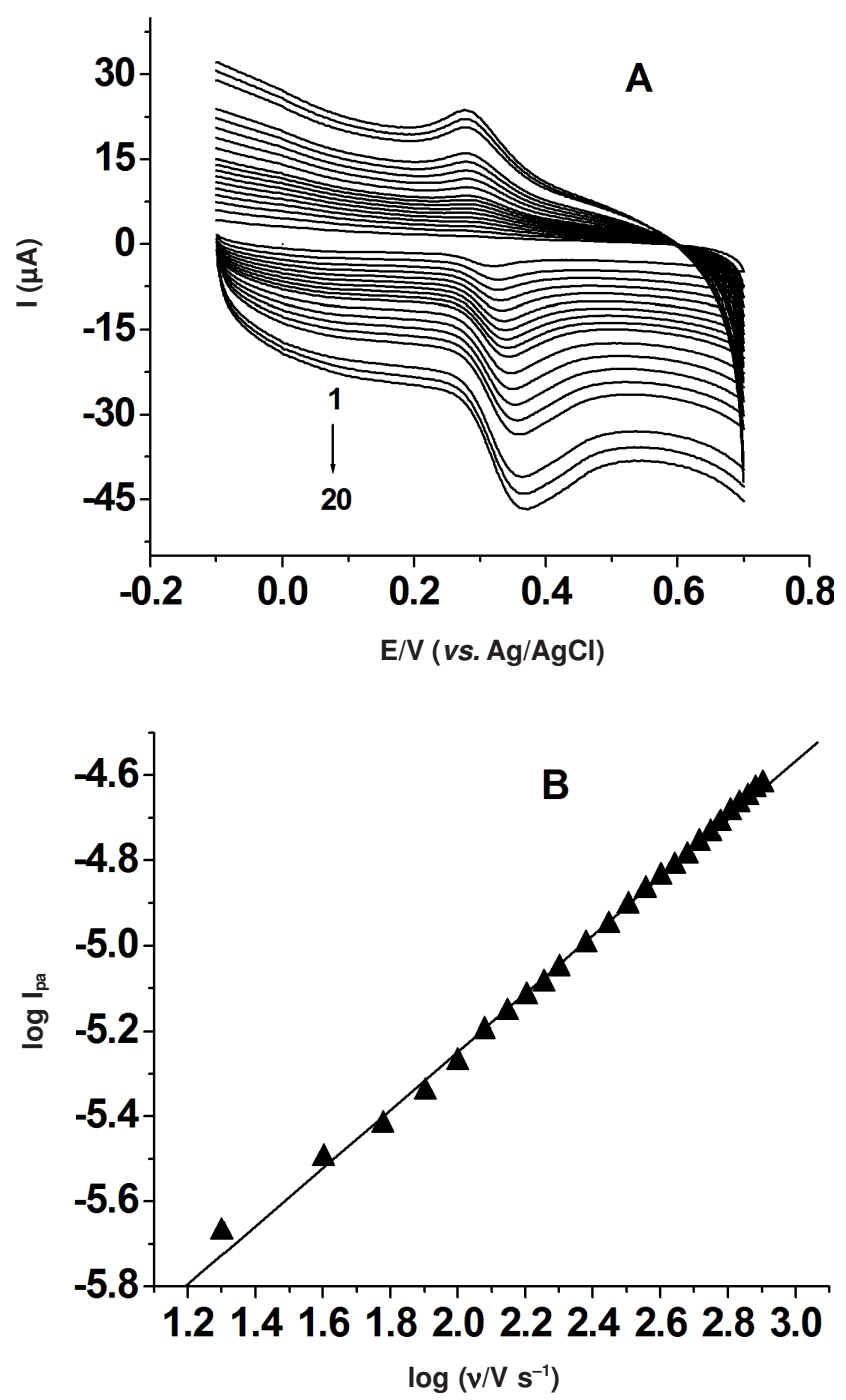

Fig. 9. (A) Cyclic voltammograms of $5.00 \times 10^{-5} \mathrm{~mol} \mathrm{~L}^{-1} \mathrm{UA}$ at Ag-PLC/ GCE in pH 7.5 PBS. Scan rate from 1 to $25: 20,40,60,80,100$, $120,140,160,180,200,240,280,320,360,400,440,480,520$, $560,600,640,680,720,760$ and $800 \mathrm{mV} \mathrm{s}^{-1}$. (B) The relationship curve between $\log \mathrm{v}$ and $\log \mathrm{I}_{\mathrm{pa}}$ 
Fig. 10. The cyclic voltammograms were obtained for the mixture of dopamine, epinephrine and uric acid at the Ag-PLC/ GCE in $\mathrm{pH} 7.5$ phosphate buffer solutions with a scan rate of $100 \mathrm{mV} \mathrm{s}^{-1}$. As shown in the Fig. 10, the anodic peaks of epinephrine and dopamine were overlapped, but their signals can be separated by cathodic peaks. From curve 1, Fig. 10, the peak responses failed to separate the peaks of them at bare GCE, but the PLC and Ag modified GCE could successfully separate the voltammetric signal of epinephrine from dopamine by 394 $\mathrm{mV} v s . \mathrm{Ag} / \mathrm{AgCl}$ with their reductive peaks and epinephrine + dopamine from uric acid by $135 \mathrm{mV} v s . \mathrm{Ag} / \mathrm{AgCl}$ with their anodic peaks, respectively. It is well known that ascorbic acid coexists with dopamine, epinephrine and uric acid in our body fluid and its concentration is much higher than that of dopamine, epinephrine and uric $\operatorname{acid}^{46}$. Therefore, the detection of dopamine, epinephrine and uric acid in the presence of high concentration of ascorbic acid is very important. From the inset (a) of Fig. 10, plentiful of ascorbic acid (ascorbic acid $=2.00 \times$ $10^{-4} \mathrm{~mol} \mathrm{~L}^{-1}$ ) has no interference with simultaneously detected of dopamine, epinephrine and uric acid. In this case, dopamine, epinephrine and uric acid can be simultaneously detected using the Ag-PLC/GCE in the presence of ascorbic acid.

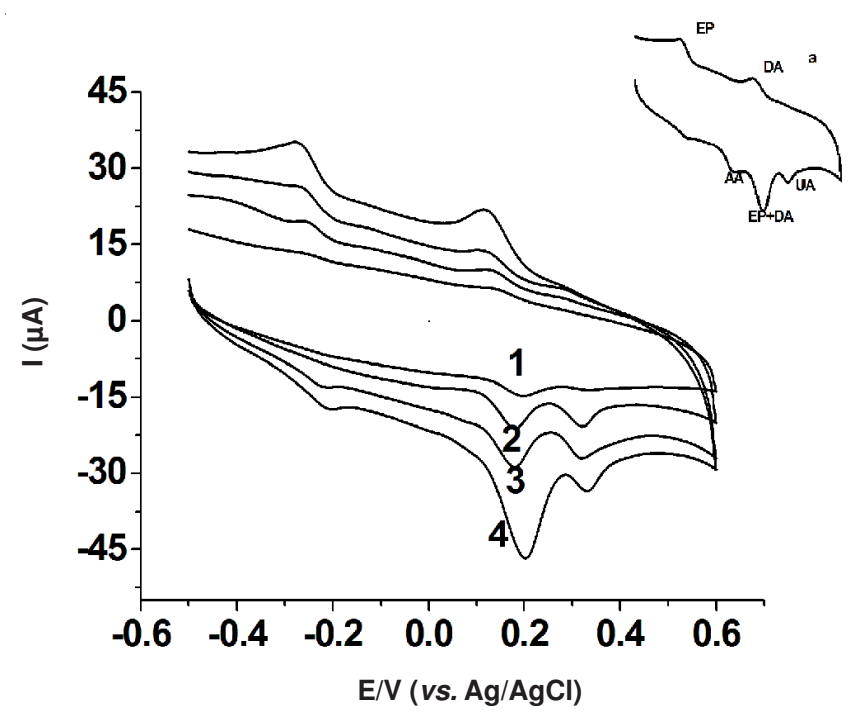

Fig. 10. CVs obtained for the mixed solution of $2.00 \times 10^{-5} \mathrm{~mol} \mathrm{~L}^{-1} \mathrm{DA}$, $1.10 \times 10^{-5} \mathrm{~mol} \mathrm{~L}^{-1} \mathrm{EP}$ and $3.00 \times 10^{-5} \mathrm{~mol} \mathrm{~L}^{-1} \mathrm{UA}$ in $\mathrm{pH} 7.5 \mathrm{PBS}$ at bare GCE (1), Ag/GCE (2), PLC/GCE (3) and Ag-PLC/GCE (4). Inset(a): CVs obtained for the mixed solution of $2.00 \times 10^{-5} \mathrm{~mol} \mathrm{~L}^{-1}$ DA, $1.10 \times 10^{-5} \mathrm{~mol} \mathrm{~L}^{-1} \mathrm{EP}, 3.00 \times 10^{-5} \mathrm{~mol} \mathrm{~L}^{-1} \mathrm{UA}$ and $2.00 \times 10^{-4}$ mol L ${ }^{-1} \mathrm{AA}$ at Ag-PLC/GCE. Scan rate: $100 \mathrm{mV} \mathrm{s}^{-1}$

Concentration determination of dopamine, epinephrine and uric acid at the Ag-PLC/GCE: The effect of solution $\mathrm{pH}$ on the electrochemical response of the PLC/GCE, Ag/GCE and Ag-PLC/GCE towards the single determination of dopamine, epinephrine and uric acid was studied. To make the experiment more biologically relevant, $\mathrm{pH} 7.5$ was selected for the electrochemical determination in present study. The experiments were performed in $0.1 \mathrm{~mol} \mathrm{~L}^{-1}$ phosphate buffer solutions by cyclic voltammetry at a scan rate of $100 \mathrm{mV} \mathrm{s}^{-1}$ with the quiet time of $8 \mathrm{~s}$. The cathodic peak current of dopamine, epinephrine and the anodic peak current of dopamine + epinephrine, uric acid were selected for the analytical measurement in this study.
Individual determination of dopamine and epinephrine: The effects of the increasing concentration of dopamine and epinephrine in the range of $0.80-500$ and $3.00-100 \mu \mathrm{mol} \mathrm{L}^{-1}$ on its voltanmograms at Ag-PLC/GCE are presented in Figs. 11 and 12 . They clearly show that the peak currents of both dopamine and epinephrine increased linearly with the concentration (0.8-30 $\mu \mathrm{mol} \mathrm{L}-1,30-500 \mu \mathrm{mol} \mathrm{L} \mathrm{L}^{-1}$ for dopamine and 3-10 $\mu \mathrm{mol}$ $\mathrm{L}^{-1}, 10-100 \mu \mathrm{mol} \mathrm{L} \mathrm{L}^{-1}$ for epinephrine, respectively) with good correlation coefficients. The linear regression equations, the correlation coefficients and the detection limit of dopamine and epinephrine were listed in Table-1.

Simultaneous determination of uric acid, epinephrine and dopamine: The main objective of this report is to determinate uric acid, epinephrine and dopamine simultaneously. The experiment was carried out in the potential range of

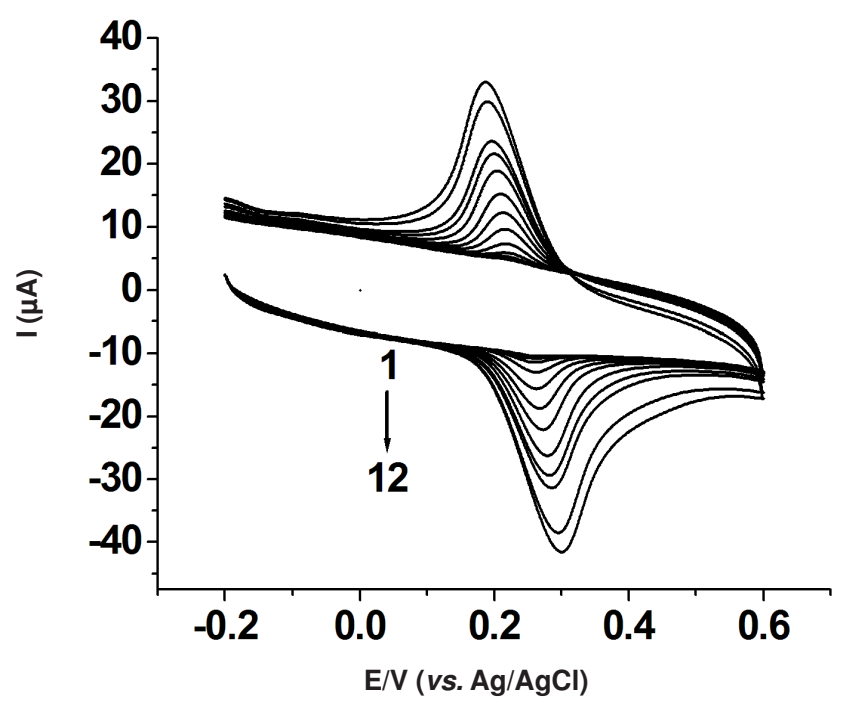

Fig. 11. CVs of various concentration of DA in PBS, pH 6.0 at Ag-PLC/ GCE. Scan rate: $100 \mathrm{mV} \mathrm{s}^{-1}$. DA concentration (curve 1-12): $8.00 \times$ $10^{-7} ; 1.00 \times 10^{-6} ; 3.00 \times 10^{-6} ; 5.00 \times 10^{-6} ; 8.00 \times 10^{-6} ; 1.00 \times 10^{-5}$; $3.00 \times 10^{-5} ; 5.00 \times 10^{-5} ; 8.00 \times 10^{-5} ; 1.00 \times 10^{-4} ; 3.00 \times 10^{-4} ; 5.00 \times$ $10^{-4} \mathrm{~mol} \mathrm{~L}^{-1}$

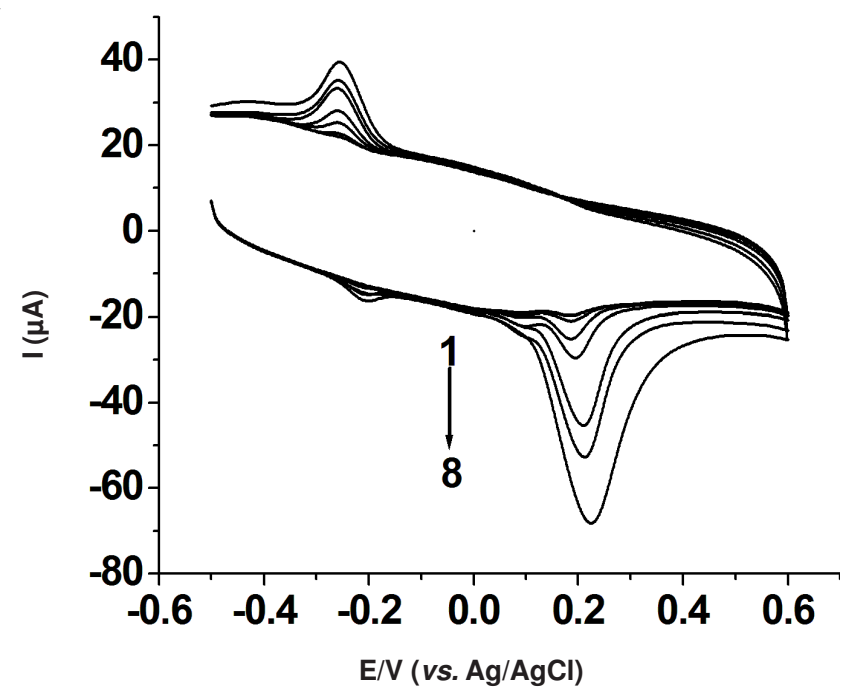

Fig. 12. Cylic voltammograms of various concentration of EP at Ag-PLC/ GCE. $\mathrm{pH} 7.5$, scan rate: $100 \mathrm{mV} \mathrm{s}^{-1}$; EP concentration(curve 1-8): $3.00 \times 10^{-6} ; 5.00 \times 10^{-6} ; 8.00 \times 10^{-6} ; 1.00 \times 10^{-5} ; 3.00 \times 10^{-5} ; 5.00 \times$ $10^{-5} ; 8.00 \times 10^{-5} ; 1.00 \times 10^{-4} \mathrm{~mol} \mathrm{~L}^{-1}$ 
TABLE-1

ANALYTICAL PARAMETERS FOR INDIVIDUAL DETERMINATION OF DOPAMINE AND EPINEPHRINE

\begin{tabular}{ccccc}
\hline Analyte & Linear range $\left(\mu \mathrm{mol} \mathrm{L}^{-1}\right)$ & Linear regression equation $\left(\mathrm{I}: \mu \mathrm{A}, \mathrm{C}: \mu \mathrm{mol} \mathrm{L} \mathrm{L}^{-1}\right)$ & Correlation coefficient $(\mathrm{r})$ & Detection limit $(\mu \mathrm{mol} \mathrm{L})$ \\
\hline \multirow{2}{*}{ Dopamine } & $0.80-30.0$ & $\mathrm{I}_{\mathrm{pc}}=0.7657+0.4228 \mathrm{C}_{\mathrm{DA}}$ & 0.9819 & 0.3 \\
& $30.0-500$ & $\mathrm{I}_{\mathrm{pc}}=12.83+0.03474 \mathrm{C}_{\mathrm{DA}}$ & 0.9947 & 0.5 \\
\multirow{2}{*}{ Epinephrine } & $3.00-10.0$ & $\mathrm{I}_{\mathrm{pc}}=-0.9893+0.6438 \mathrm{C}_{\mathrm{EP}}$ & 0.9972 & 0.9946 \\
& $10.0-100$ & $\mathrm{I}_{\mathrm{pc}}=3.995+0.1263 \mathrm{C}_{\mathrm{EP}}$ & 0.996 & \\
\hline
\end{tabular}

TABLE-2

ANALYTICAL PARAMETERS FOR DETERMINATION OF URIC ACID, EPINEPHRINE AND DOPAMINE (KEEPING THE CONCENTRATIONS OF TWO OTHER COMPOUNDS CONSTANT)

\begin{tabular}{|c|c|c|c|c|}
\hline Analyte & Linear rang $\left(\mu \mathrm{mol} \mathrm{L}^{-1}\right)$ & Linear regression equation $\left(\mathrm{I}: \mu \mathrm{A}, \mathrm{C}: \mu \mathrm{mol} \mathrm{L}^{-1}\right)$ & Correlation coefficient (r) & Detection limit $\left(\mu \mathrm{mol} \mathrm{L}{ }^{-1}\right)$ \\
\hline \multirow{2}{*}{ Uric acid } & $5.0-80.0$ & $\mathrm{I}_{\mathrm{pa}}=1.945+0.1544 \mathrm{C}_{\mathrm{UA}}$ & 0.9933 & \multirow{2}{*}{1.0} \\
\hline & $80.0-200.0$ & $\mathrm{I}_{\mathrm{pa}}=10.74+0.04044 \mathrm{C}_{\mathrm{UA}}$ & 0.9974 & \\
\hline \multirow{2}{*}{ Dopamine } & $5.0-30.0$ & $\mathrm{I}_{\mathrm{pc}}=0.8475+0.2986 \mathrm{C}_{\mathrm{DA}}$ & 0.9907 & \multirow{2}{*}{0.5} \\
\hline & $30.0-200.0$ & $\mathrm{I}_{\mathrm{pc}}=7.864+0.08188 \mathrm{C}_{\mathrm{DA}}$ & 0.9919 & \\
\hline \multirow{2}{*}{ Epinephrine } & $3.0-10.0$ & $\mathrm{I}_{\mathrm{pc}}=0.1605+0.8786 \mathrm{C}_{\mathrm{EP}}$ & 0.9965 & \multirow{2}{*}{0.8} \\
\hline & $10.0-100.0$ & $\mathrm{I}_{\mathrm{pc}}=8.370+0.08924 \mathrm{C}_{\mathrm{EP}}$ & 0.9904 & \\
\hline
\end{tabular}

-0.5-0.6 V ( $\mathrm{pH} 7.5$ ). The utilization of the Ag-PLC/GCE for the simultaneous determination of uric acid, epinephrine and dopamine was demonstrated by changing the concentration of one species, whereas the other two species were kept constant. The results are shown in Fig. 13. Fig. 13A shows that various concentrations of uric acid in the presence of $2.00 \times 10^{-5} \mathrm{~mol} \mathrm{~L}^{-1}$ dopamine and $1 \times 10^{-5} \mathrm{~mol} \mathrm{~L}^{-1}$ epinephrine in $0.1 \mathrm{~mol} \mathrm{~L}^{-1}$ phosphate buffer solutions ( $\mathrm{pH}$ 7.5) exhibit excellent cyclic voltammogram responses. The peak current of uric acid increased with the increasing concentration when the peak currents of dopamine and epinephrine were kept almost unchanged. Fig. $13 \mathrm{~B}$ and $\mathrm{C}$ show, when keeping the concentrations of dopamine and epinephrine constant respectively, the cathodic peak current of these two compounds was proportional to its concentration, while the other two compounds fragment were kept unchanged. The linear regression equations, the correlation coefficients and the detection limit are listed in Table-2.

The simultaneous determination of uric acid, dopamine and epinephrine in a mixture which was increased the concentrations synchronously at the Ag-PLC/GCE were also investigated (Fig. 14). It depicts the cyclic voltammograms obtained at Ag-PLC/GCE when simultaneously changing the concentration of uric acid, dopamine and epinephrine in phosphate buffer solutions.

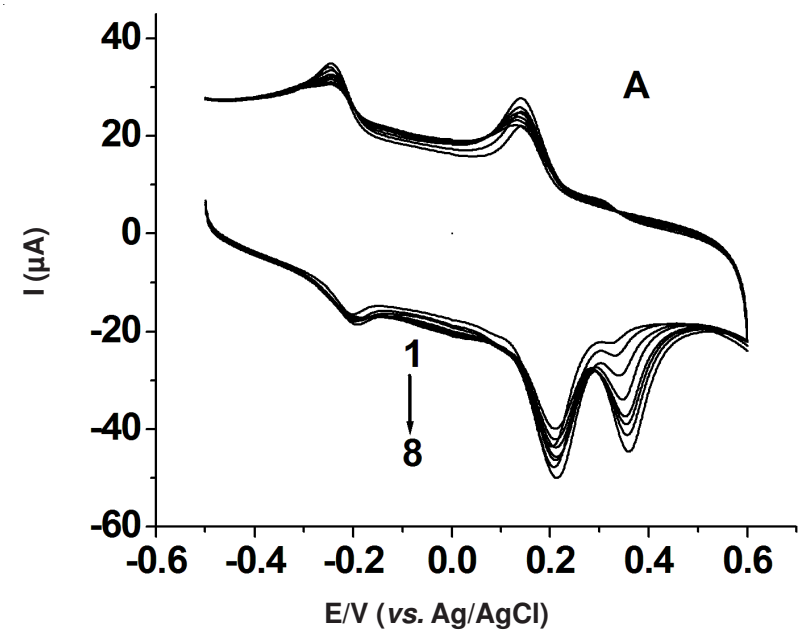

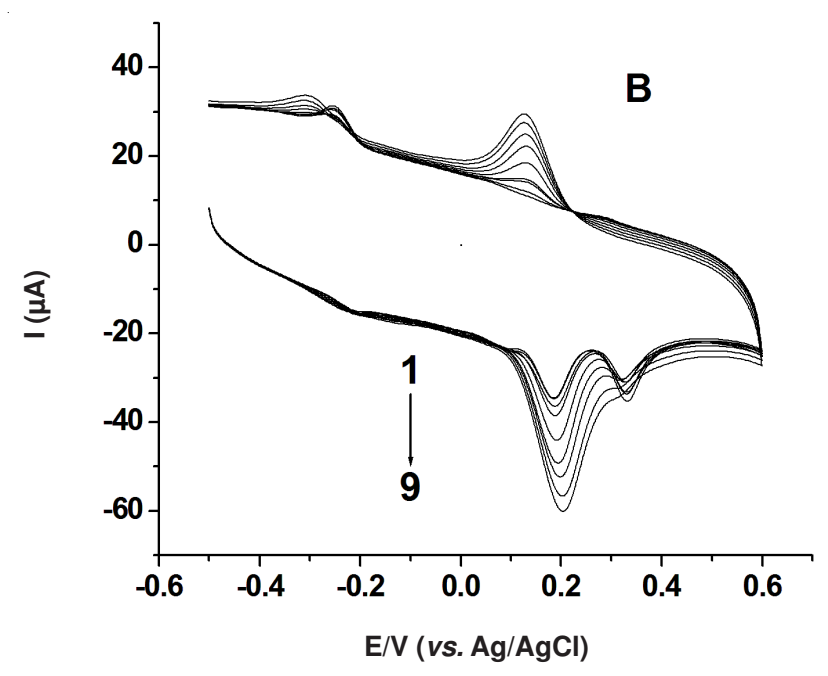

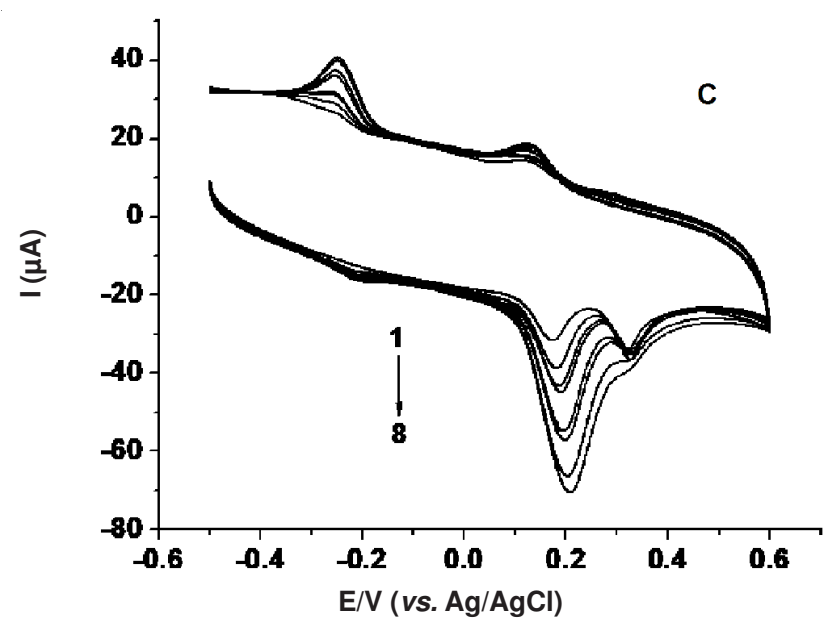

Fig. 13. (A) CVs of UA at Ag-PLC/GCE in the presence of $2.00 \times 10^{-5} \mathrm{~mol}$ $\mathrm{L}^{-1} \mathrm{DA}$ and $1.00 \times 10^{-5} \mathrm{~mol} \mathrm{~L}^{-1} \mathrm{EP}$ in $\mathrm{pH} 7.5 \mathrm{PBS}$. UA concentrations (from 1 to 8):5.0, 10.0, 25.0, 50.0, 80.0, 100.0, 150.0, $200.0 \mu \mathrm{mol}$ $\mathrm{L}^{-1}$. (B) CVs of DA at Ag-PLC/GCE in the presence of $3.00 \times 10^{-5}$ mol L ${ }^{-1} \mathrm{UA}$ and $1.00 \times 10^{-5} \mathrm{~mol} \mathrm{~L}^{-1} \mathrm{EP}$ in $\mathrm{pH} 7.5 \mathrm{PBS}$. DA concentrations (from 1 to 9): $3.0,5.0,8.0,10.0,30.0,50.0,80.0$, 100.0, $200.0 \mu \mathrm{mol} \mathrm{L}^{-1}$. (C) CVs of EP at Ag-PLC/GCE in the presence of $3.00 \times 10^{-5} \mathrm{~mol} \mathrm{~L}^{-1} \mathrm{UA}$ and $2.00 \times 10^{-5} \mathrm{~mol} \mathrm{~L}^{-1} \mathrm{DA}$ in $\mathrm{pH}$ 7.5 PBS. EP concentrations (from 1 to 8): 3.0, 5.0, 8.0, 10.0, 30.0, $50.0,80.0,100.0 \mu \mathrm{mol} \mathrm{L}^{-1}$. Scan rate: $100 \mathrm{mV} \mathrm{s}^{-1}$ 
TABLE-3

ANALYTICAL PARAMETERS FOR SIMULTANEOUS DETERMINATION OF UA, DA AND EP

\begin{tabular}{ccccc}
\hline Analyte & Linear rang $\left(\mu \mathrm{mol} \mathrm{L}^{-1}\right)$ & Linear regression equation $\left(\mathrm{I}: \mu \mathrm{A}, \mathrm{C}: \mu \mathrm{mol} \mathrm{L}^{-1}\right)$ & Correlation coefficient $(\mathrm{r})$ & Detection limit $\left(\mu \mathrm{mol} \mathrm{L}^{-1}\right)$ \\
\hline \multirow{2}{*}{ Uric acid } & $5.0-50.0$ & $\mathrm{I}_{\mathrm{pa}}=0.3037+0.08980 \mathrm{C}_{\mathrm{UA}}$ & 0.9972 & 3.0 \\
& $50.0-250.0$ & $\mathrm{I}_{\mathrm{pa}}=4.215+0.01224 \mathrm{C}_{\mathrm{UA}}$ & 0.9926 & 0.8 \\
\hline Dopamine & $5.0-110.0$ & $\mathrm{I}_{\mathrm{pc}}=2.528+0.1171 \mathrm{C}_{\mathrm{DA}}$ & 0.9955 & 0.8 \\
\hline \multirow{2}{*}{ Epinephrine } & $5.0-30.0$ & $\mathrm{I}_{\mathrm{pc}}=3.396+0.2317 \mathrm{C}_{\mathrm{EP}}$ & 0.9905 & 0.9931 \\
& $30.0-110.0$ & $\mathrm{I}_{\mathrm{pc}}=9.537+0.02137 \mathrm{C}_{\mathrm{EP}}$ & & \\
\hline
\end{tabular}

TABLE-4

SINGLE ANALYTICAL RESULTS OF DA AND EP INJECTION SAMPLES $(n=6)$

\begin{tabular}{cccccc}
\hline Sample & Recommended $\left(\times 10^{-5} \mathrm{~mol} \mathrm{~L}^{-1}\right)$ & Found $\left(\times 10^{-5} \mathrm{~mol} \mathrm{~L}^{-1}\right)$ & $\mathrm{RSD}(\%)$ & Added $\left(\times 10^{-5} \mathrm{~mol} \mathrm{~L}^{-1}\right)$ & Recovery $(\%)$ \\
\hline $\begin{array}{c}\text { Dopamine } \\
\text { injection }\end{array}$ & 5.0 & 4.835 & 3.31 & 5.0 & $\begin{array}{c}100.81 \\
9.0\end{array}$ \\
\hline $\begin{array}{c}\text { Epinephrine } \\
\text { injection }\end{array}$ & 5.0 & 4.788 & \multirow{2}{*}{1.14} & 5.0 & 98.11 \\
\hline
\end{tabular}

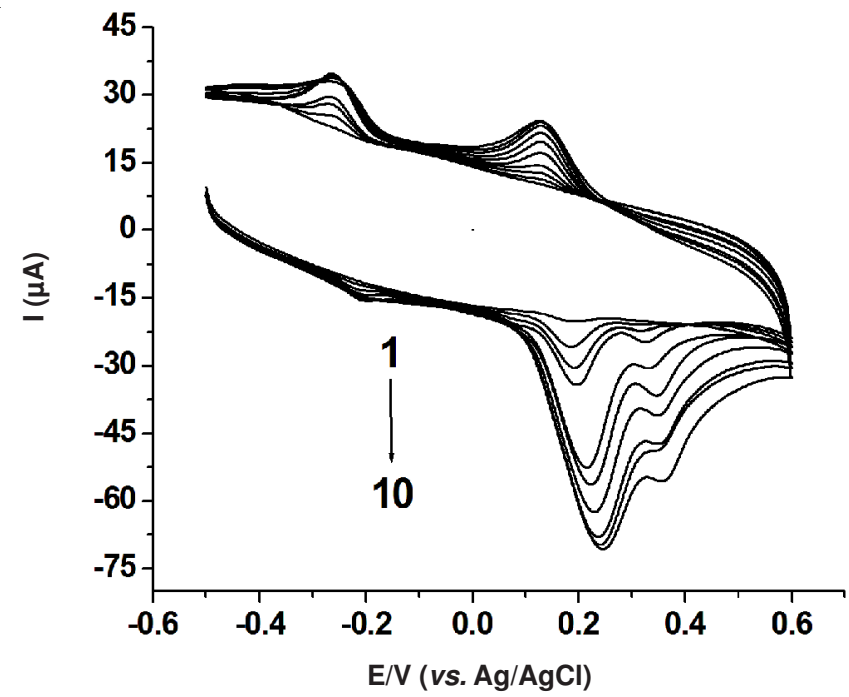

Fig. $14 \mathrm{CVs}$ obtained for the determination of UA, DA and EP at the Ag$\mathrm{PLC} / \mathrm{GCE}$ in $\mathrm{pH} 7.5 \mathrm{PBS}$. Concentrations of the analytes were changed simultaneously. From 1 to 10 : UA: 3.0, 5.0, 8.0, 10.0, $30.0,50.0,100.0,140.0,150.0,250.0 \mu \mathrm{mol} \mathrm{L}^{-1}$; DA: 3.0, 5.0, 8.0, 10.0, 30.0, 50.0, 70.0, 90.0, 100.0, $110.0 \mu \mathrm{mol} \mathrm{L}{ }^{-1}$; EP: 5.0, 8.0, 10.0, 30.0, 50.0, 70.0, 90.0, 100.0, 100.0, $110.0 \mu \mathrm{mol} \mathrm{L}^{-1}$. Scan rate: $100 \mathrm{mV} \mathrm{s}^{-1}$

Under the optimum conditions, a linear correlation was observed between the peak currents and concentrations of uric acid, dopamine, epinephrine, respectively. The analytical parameters for the simultaneous determination of uric acid, dopamine and epinephrine are given in Table-3.

Reproducibility and stability of the modified electrode: The stability and reproducibility of the electrode were examined in three parallel experiments. The relative standard deviations were $3.1,1.7$ and $1.3 \%$ for the determination of $5 \times 10^{-5} \mathrm{~mol}$ $\mathrm{L}^{-1}$ uric acid, $5 \times 10^{-5} \mathrm{~mol} \mathrm{~L}^{-1}$ dopamine and $5 \times 10^{-5} \mathrm{~mol} \mathrm{~L}^{-1}$ epinephrine solution, respectively $(n=11)$. When the modified electrode was stored in $0.1 \mathrm{~mol} \mathrm{~L}^{-1}$ phosphate buffer solutions at room temperature for 30 days, the same shape of the voltammetric curves of dopamine, epinephrine and uric acid could be maintained, indicating a better stability and reproducibility of the Ag-PLC/GCE.

Interference: Ascorbic acid is widely coexisted with uric acid, dopamine and epinephrine in real biological matrices and therefore, avoiding ascorbic acid interference is an important target for uric acid, dopamine and epinephrine analytical methods. In our study, as shown in Fig. 11(a), plentiful of ascorbic acid $\left(\mathrm{c}_{\mathrm{AA}}=2.00 \times 10^{-4} \mathrm{~mol} \mathrm{~L}^{-1}\right)$ has no interference when simultaneously detecting to dopamine, epinephrine and uric acid.

In order to investigate the interference, foreign compounds were selected. The tolerance limit was taken as the maximum concentration of the foreign substances, which caused an approximately $\pm 5 \%$ relative error, for $3.00 \times 10^{-5} \mathrm{~mol} \mathrm{~L}^{-1}$ uric acid, $2.00 \times 10^{-5} \mathrm{~mol} \mathrm{~L}^{-1}$ dopamine and $1.10 \times 10^{-5} \mathrm{~mol} \mathrm{~L}^{-1}$ epinephrine. The errors were detected by comparison with peak currents given by a solution of analyte containing no foreign substances. The result indicated a series of amino acid $(>1.00$ $\times 10^{-3} \mathrm{~mol} \mathrm{~L}^{-1}$ ) have no interference with uric acid, dopamine and epinephrine detection. The following compounds had no interference (mg/10 mL): $\mathrm{Zn}^{2+}, \mathrm{Ca}^{2+}, \mathrm{Mn}^{2+}, \mathrm{K}^{+}, \mathrm{Na}^{+}, \mathrm{Sr}^{2+}, \mathrm{Cr}^{3+}$, $\mathrm{Ba}^{2+}, \mathrm{Cu}^{2+}, \mathrm{Cd}^{2+}, \mathrm{V}^{5+}, \mathrm{Ag}^{+}, \mathrm{Cl}^{-}, \mathrm{Fe}^{3+}(>1.0), \mathrm{Cr}(\mathrm{VI})(0.90), \mathrm{Pb}^{2+}$ (0.80), $\mathrm{I}^{-}(0.70), \mathrm{Co}^{2+}(0.55), \mathrm{Bi}^{3+}, \mathrm{Mg}^{2+}(0.20)$. Therefore, it is possible to simultaneously determine uric acid, dopamine and epinephrine in the sample at an Ag-PLC/GCE.

Samples analysis: In order to verify reliability of AgPLC/GCE for analysis of uric acid dopamine and epinephrine, the determination of the dopamine hydrochloride injection and epinephrine hydrochloride injection were both diluted to reach a solution of $10 \mathrm{mmol} \mathrm{L}{ }^{-1}$ with water. Then, $0.5 \mathrm{~mL}$ of the diluted solution and some amount of standard solution were injected into a $10 \mathrm{~mL}$ electrolytic cell and made up to volume with $0.1 \mathrm{~mol} \mathrm{~L}^{-1}$ phosphate buffer solutions (dopamine in $\mathrm{pH} 6.0$ and epinephrine in $\mathrm{pH}$ 7.5) and then the voltammo- grams of dopamine and epinephrine were obtained under the optimum conditions. The results are listed in Table- 4 .

The electrode was demonstrated for the recovery determination by measuring the concentration of uric acid, dopamine and epinephrine which were spiked into human urine samples. Human urine samples were selected as real samples for analysis by the proposed method using the standard addition method. In other words, the experiment was carried out by the addition of standard of uric acid, dopamine and epinephrine. The fresh human urine samples were prepared without any preparation. The sample urine was diluted with 0.1 mol L ${ }^{-1}$ pH 7.5 phosphate buffer solutions and an appropriate amount of these diluted samples were transferred to the electrochemical cell for the determination of each species using 
TABLE-5

ANALYTICAL RESULTS OF UA, DA AND EP IN REAL URINE SAMPLES WITH Ag-PLC /GCE ( $\mathrm{n}=6)$

\begin{tabular}{|c|c|c|c|c|c|c|}
\hline & Sample & Detected $\left.(\mu \mathrm{mol} \mathrm{L})^{-1}\right)$ & Mean $\left(\mu \mathrm{mol} \mathrm{L}{ }^{-1}\right)$ & RSD (\%) & $\operatorname{Added}\left(\mu \mathrm{mol} \mathrm{L}^{-1}\right)$ & Recovery (\%) \\
\hline \multirow{3}{*}{ Urine } & Uric acid & 37.8 & 109.1 & 3.4 & 20 & 100.67 \\
\hline & Dopamine & $\sim 0$ & $\sim 0$ & & $\begin{array}{l}50 \\
50\end{array}$ & $\begin{array}{c}99.77 \\
100.04\end{array}$ \\
\hline & Epinephrine & $\sim 0$ & $\sim 0$ & & $\begin{array}{l}5.0 \\
5.0\end{array}$ & $\begin{array}{c}97.96 \\
100.37\end{array}$ \\
\hline
\end{tabular}

cyclic voltammogram. The analysis of these data shows that the modified electrode has excellent detection to determine uric acid, dopamine and epinephrine in clinical and pharmaceutical preparations (Table-5).

\section{Conclusion}

Simultaneous determination of uric acid, dopamine and epinephrine was achieved by cyclic voltammetry using the Ag-PLC/GCE. In $\mathrm{pH} 7.5$ phosphate buffer solutions, the electrode showed good electrocatalytic activity for uric acid, dopamine and epinephrine. The peak separations between uric acid, dopamine and epinephrine were obviously shown in cyclic voltammograms and a plenty of ascorbic acid did not influence them, but can also be detected synchronously. The results indicated that the modified electrode facilitates the simultaneous determination of uric acid, dopamine and epinephrine with attractive properties, such as reproducibility, simple fabrication procedure, wide linear dynamic range, high stability and a distinct advantage of polishing in the event of surface fouling. The effects of potential interfering ions were studied and it was found that the proposed procedure was without interferences of most common interfering ions such as amino acids and commonly interfering species. The proposed method can be considerably applied to the determination of uric acid, dopamine and epinephrine in injection solution and real urine samples with satisfactory results.

\section{ACKNOWLEDGEMENTS}

The present work was financially supported by the Natural Science Foundation of Anhui Province Ministry of Education (KJ2008A122) and the Foundation of Anhui Key Laboratory of Energetic Materials (KLEM2009008).

\section{REFERENCES}

1. P. Capella, B. Ghasemzadech, K. Mitchekk and R.N. Adams, Electroanalysis, 2, 175 (1990).

2. A. Carlsson, L.O. Hansson, N. Waters and M.L. Carlsson, Life Sci., 61, 75 (1997).

3. S.A. Azizi, Parkinson's Disease, Encyclopedia of Behavioural Neuroscience, Elsevier Ltd., p. 24 (2010).

4. M.C. Gancia and J. Escamilla-Sanchez, Can. J. Physiol. Pharm., 72, 1580 (1994).

5. N. Nakao and T. Itakura, Prog. Neurobiol., 61, 313 (2000).

6. T.N. Deftereos, A.C. Calokerinos and C.E. Efstathiou, Analyst, 118, 627 (1993).

7. G.L. Patric, An Introduction to Medical Chemistry, Oxford University Press (2005).

8. L.A. Pachla, D.L. Reynolds, D.S. Wright and P.T. Kissinger, J. Assoc. Off. Anal. Chem., 70, 1 (1987).

9. V.V.S.E. Dutt and H.A. Mottola, Anal. Chem., 46, 1777 (1974).

10. E. Liberopoulos, D. Christides and E. Moses, J. Hypertens., 20, 347 (2002).
11. R.J. Johnson, D.K. Kang, D. Feig, S. Kivlighn, J. Kanellis, S. Watanabe, K.R. Tuttle, B. Rodriguez-Iturbe, J. Herrera-Acosta and M. Mazzali, Hypertension, 41, 1183 (2003).

12. O. Arrigoni and M.C. De Tullio, Biochim. Biophys. Acta, 1569, 1 (2002).

13. S.F. Fabiana, Y. Miyuki and A. Lúcio, Biosens. Bioelectron., 21, 2283 (2006).

14. S.L. Zhao, J.S. Wang, F.G. Ye and Y.M. Liu, Anal. Biochem., 378, 127 (2008).

15. Y.H. Wang, K.Y. Chan and X.Y. Li, Chemosphere, 65, 1087 (2006).

16. L.S. Andrade, L.A.M. Ruotolo, R.C. Rocha-Filho, N. Bocchi, S.R. Biaggio, J. Iniesta, V.G. Garcia and V. Montiel, Chemosphere, 66, 2035 (2007).

17. T. Ohno, S. Izumi, K. Fujihara and M. Matsumura, J. Photochem. Photobiol. A, 129, 143 (1999).

18. Y. Li and X. Lin, Sens. Actuators B, 115, 134 (2006).

19. Y.Q. Wang, H.M. Cheng, Y.Z. Hao, J.M. Ma, W.H. Li and S.M. Cai, Thin Solid Films, 349, 120 (1999).

20. J. Premkumar and S.B. Khoo, J. Electroanal. Chem., 576, 105 (2005).

21. S. Gaspar, L. Muresan, A. Patrut and I.C. Popescu, Anal. Chim. Acta, 385, 111 (1999).

22. D.M. Sun, W.N. Hu and W. Ma, Chinese J. Anal. Chem., 25, 913 (2008).

23. A.C. Lin, D.C. Chen, C.C. Lin, H.H. Chou and C.H. Chen, Anal. Chem., 71, 1549 (1999).

24. D.M. Sun, W.N. Hu and W. Ma, Chinese J. Appl. Chem., 25, 913 (2008).

25. K. Boonsong, S. Chuanuwatanakul, N. Wangfuengkanagul and O. Chailapakul, Sens. Actuators B, 108, 627 (2005).

26. C.Y. Zhi, J.D. Guo, X.D. Bai and E.G. Wang, J. Appl. Phys., 91, 5325 (2002).

27. M. Vidotti, R. Salvador and S. Cordobadetorresi, Ultrason. Sonochem., 16, 35 (2009).

28. A. Babaei, M. Zendehdel, B. Khalilzadeh and A. Taheri, Colloid Surf. B, 66, 226 (2008).

29. L.S. Andrade, L.A.M. Ruotolo, R.C. Rocha-Filho, N. Bocchi, S.R. Biaggio, J. Iniesta, V. Garcia-Garcia and V. Montiel, Chemosphere, 66, 2035 (2007).

30. R. Berenguer, C. Quijada and E. Morallón, Electrochim. Acta, 54, 5230 (2009).

31. Y.Q. Wang, H.M. Cheng, Y.Z. Hao, J.M. Ma, W.H. Li and S.M. Cai, Thin Solid Films, 349, 120 (1999).

32. Y. Liu, H.L. Liu, J. Ma and X. Wang, Appl. Catal. B, 91, 284 (2009).

33. W.N. Hu, D.M. Sun and W. Ma, Chem. Anal. (Warsaw), 53, 703 (2008).

34. R.D. O'Neill, Analyst, 119, 767 (1994).

35. H.R. Zare, F. Memarzadeh, M.M. Ardakani, M. Namazian and S.M. Golabi, Electrochim. Acta, 50, 3495 (2005).

36. J.X. Qiao, H.Q. Luo and N.B. Li, Colloid Surf. B, 62, 31 (2008).

37. E. Shams, A. Babaei, A.R. Taheri and M. Kooshki, Bioelectrochemistry, 75, 83 (2009).

38. M. Mazloum-Ardakani, H. Beitollahi, B. Ganjipour, H. Naeimi and M. Nejati, Bioelectrochem., 75, 1 (2009).

39. W. Ren, H.Q. Luo and N.B. Li, Biosens. Bioelectron., 21, 1086 ( 2006).

40. G.P. Jin, X. Penga and Y.F. Ding, Biosens. Bioelectron., 24, 1031 (2008).

41. J. Wang, Analytical Electrochemistry, Wiley, New York, edn 2, p. 31 (2001).

42. S.M. Chen and M.I. Liu, J. Electroanal. Chem., 579, 153 (2005).

43. E. Laviron, J. Electroanal. Chem., 101, 19 (1979).

44. W. Ma and D.M. Sun, Chinese J. Anal. Chem., 35, 66 (2007).

45. G. Dryhurst, J. Electrochem. Soc., 119, 1659 (1972).

46. T. Zetterstrom, T. Sharp, C.A. Marsden and U. Ungerstedt, J. Neurochem., 41, 1769 (1983). 